\title{
The Climate Change Imperative to Transform Disaster Risk Management
}

\author{
Robert Glasser ${ }^{1}$
}

Published online: 10 February 2020

(C) The Author(s) 2020

This year the international community marks the fifth anniversary of the Sendai Framework for Disaster Risk Reduction 2015-2030 (SFDRR), in which countries committed to curbing the impact of natural and human-caused hazards. While there has clearly been progress in the implementation of the Sendai Framework (UNISDR 2017), the evidence suggests that overall countries are falling short of achieving many of its objectives (UNISDR 2015). This is primarily because the objectives are extremely ambitious. Delivering on both the letter and spirit of the Sendai Framework requires nothing short of a transformation in economic and social planning and investments to incorporate disaster risk at national, state, and local levels, in the public and private sectors, and across civil society. It is not only extremely difficult to achieve this transformation, but also increasingly urgent-not simply to meet the Sendai Framework's 2030 deadline, but because of climate change.

Climate Change is significantly increasing the likelihood of compound hazards and cascading impacts on society (Glasser 2019). It is transforming disaster risk in at least four main ways. First, it is increasing the severity of many sudden-onset hazards, such as cyclones, floods, and bushfires (Schiermeier 2018). With respect to floods, for example, warmer air holds more moisture, and this increases the likelihood of extreme rainfall. Hurricane

Visiting Fellow, Australian Strategic Policy Institute and previously the United Nations Secretary General's Special Representative for Disaster Risk Reduction.

Robert Glasser

robertglasser@aspi.org.au

1 Australian Strategic Policy Institute, Canberra, Australia

Harvey, which in a short time dumped $1270 \mathrm{~mm}$ (equivalent to 127 billion tons) of water on the US Gulf States, is indicative of the scale of the emerging threat. The cascading impacts of the record rains were enormous (Sneed 2018): flooding impeded evacuations, caused power outages, spread dangerous pathogens from overrun wastewater treatment plants, and shut down one-fourth of US oil production in the Gulf of Mexico, raising petrol prices.

Second, climate change is increasing the frequency of many sudden-onset hazards. As EASAC (2018) points out:

The number of floods and other hydrological events have quadrupled since 1980 and have doubled since 2004 ...Climatological events, such as extreme temperatures, droughts, and forest fires, have more than doubled since 1980. Meteorological events, such as storms, have doubled since 1980.

As the frequency of these hazards increases, the likelihood of hazards striking simultaneously and in closer succession will grow as will opportunities for cascading impacts.

Simultaneous hazards periodically occur as part of natural climate variation, for example linked to phases of the El Nino Southern Oscillation (ENSO) (NOAA 2019). Scientists expect $1.5^{\circ}$ of warming will double the frequency of extreme El Nino events (Wang et al. 2017). Scientists (for example, Rahmstorf 2004) also suspect that climate change is altering the Northern Hemisphere jet stream, contributing to simultaneous extreme weather events (for example, heat waves, droughts, and fires in some regions, floods in others) on a global scale. The scale of the damage and potential for wider cascading impacts are greater when major hazards strike simultaneously or in closer succession.

Third, climate change is altering other aspects of the pattern of occurrence of extreme events. An example of 
this is Sharmila and Walsh (2018), suggesting that climate change is shifting tropical cyclones into new areas of Eastern Australia, where many structures have not been built to withstand intense cyclones. Similarly, scientists project that wildfires are not only likely to increase, but also that the bushfire season will lengthen (Harvey 2017). This is already noticeable in places such as California (Cal Fire 2019) in the United States, and in Australia (BoM 2020). Storms carrying more moisture additionally create opportunities for severe flooding to occur in new locations. More than half of the homes damaged from Hurricane Harvey's flooding, for example, were outside of the 500-year flood plain (Hunn et al. 2018). These changing patterns of hazards increase the likelihood of surprises that will overwhelm coping capacity and increase the likelihood of cascading impacts.

Fourth, climate change is increasing slow-onset hazards that can greatly magnify the impact of sudden-onset hazards. Even small increases in average global temperatures can cause temperature extremes to become much more frequent and intense. For example, analysis has shown that the percentage of the planet experiencing extremely hot temperatures jumped from some $0.1-0.2 \%$ in the period from 1951 to 1980 to $10 \%$ in the subsequent 3 decades (Hansen et al. 2012). Rising temperatures and droughts will gradually push places that are currently marginally viable for agriculture into chronic crisis and make communities more vulnerable to the outbreak of bushfires that droughts and extreme temperatures are making more likely.

While climate change is an enormous threat, it is also an opportunity; the climate emergency may ultimately help mobilize the political will and resources required to achieve the transformation in risk management called for in the Sendai Framework.

There are places where disaster risk is already being incorporated in core economic planning (SPC et al. 2016). But this tends to be primarily where disasters are already a major drain on economic development. For decision makers in many other countries, however, the annual costs of disasters currently seem too small to trigger the transformation in risk management called for in the Sendai Framework.

This is not surprising given that there are many competing global challenges that involve costs similar to the USD 520 billion in annual losses from disasters (World Bank 2016). For example, the annual cost to the global health sector of smoking is USD 422 billion (Goodchild et al. 2018); of child abuse and neglect in East Asia and the Pacific is USD 209 billion (Whiting 2015); of deforestation is USD 2-5 trillion (Schmidt 2008); of malnutrition is USD 3.5 trillion (Global Panel 2016); and of avoidable blindness is USD 632 billion (Armstrong et al. 2012). The business case for investment in disaster risk reduction is very compelling, but it is also compelling for many other investments.

But climate change, as a global systemic risk, is rapidly altering these financial calculations. Influential institutions and actors across the global financial sector are increasingly moving from treating climate change as a public relations matter to seeing it as a core business risk (and opportunity). The work of the Task Force on Climate-Related Financial Disclosures ${ }^{1}$ is quickly gaining traction. The voluntary disclosure of material on climate-related risks promoted by the Task Force is now supported by three-quarters of the world's globally systemic banks, eight of the top 10 global asset managers, the world's leading pension funds and insurers, major credit-rating agencies, and the big four accounting and consulting firms. Together these institutions manage almost USD 110 trillion in assets.

The voluntary reporting focuses on financial losses resulting from the sudden-onset hazards (such as wildfires, droughts, floods, storms, and heatwaves) that climate change is amplifying and from progressively intensifying hazards (such as sea-level rise, changes in rainfall patterns, and increasing temperatures).

Ultimately, the voluntary reporting is likely to become mandatory and the methodology underpinning it more rigorous. As it does, it will unlock enormous amounts of investment capital to be shifted away from assets that are exposed to disaster risk towards investments in resilience.

Tools are being developed to help markets and managers make climate-smart investments. Global Infrastructure Basel, ${ }^{2}$ for example, is developing a standard for a resilient asset class. Credit-rating agencies, such as Moody's (2017), are factoring climate shocks into their analysis of municipal bond issuers' economies, fiscal position, and capital investments.

The increasing scale of the economic costs of climate change is already leading financial regulators and the private sector to accelerate the transformation in risk management. In this respect, they are moving faster than many governments to incorporate disaster risk in their planning and investments.

The challenge before us is that the window of opportunity to prevent catastrophic climate change is closing rapidly (IPCC 2018). The Intergovernmental Panel on Climate Change (IPCC 2018) determined that the planet is likely to warm by $1.5{ }^{\circ} \mathrm{C}$ (the lower limit set in the Paris Climate Agreement) as early as 2030 and highlighted the enormous challenge of preventing further warming. Annual emissions of carbon dioxide would need to be halved by 2030 relative to 2016 levels, and renewable energy sources would need to supply $70-85 \%$ of global electricity demand

\footnotetext{
${ }^{1}$ https://www.fsb-tcfd.org.

${ }^{2}$ https://gib-foundation.org.
} 
(and coal's contribution essentially cease) by 2050. It noted that systemic changes on that scale would be historically unprecedented and require "deep emissions reductions in all sectors, a wide portfolio of mitigation options and a significant upscaling of investments in those options" (IPCC 2018, p. 15).

Climate Action Tracker (2019) suggests that, without far greater commitment from governments to reduce greenhouse gases, the planet is likely to warm by close to $3^{\circ}$. Warming on this scale would be catastrophic (Glasser 2019). Clearly the single most urgent disaster risk treatment is to reduce greenhouse gases as rapidly as possible. The finance and private sectors are currently leading the transformation in risk management called for in the Sendai Framework, but governments can and must now do everything in their power to accelerate it.

Open Access This article is licensed under a Creative Commons Attribution 4.0 International License, which permits use, sharing, adaptation, distribution and reproduction in any medium or format, as long as you give appropriate credit to the original author(s) and the source, provide a link to the Creative Commons licence, and indicate if changes were made. The images or other third party material in this article are included in the article's Creative Commons licence, unless indicated otherwise in a credit line to the material. If material is not included in the article's Creative Commons licence and your intended use is not permitted by statutory regulation or exceeds the permitted use, you will need to obtain permission directly from the copyright holder. To view a copy of this licence, visit http://creativecommons. org/licenses/by/4.0/.

\section{References}

Armstrong, K.L., M. Jovic, J.L. Vo-Phuoc, J.G. Thorpe, and B.L. Doolan. 2012. The global cost of eliminating avoidable blindness. Indian Journal of Ophthalmology 60(5): 475-480.

BoM (Bureau of Meteorology, Australian Government). 2020. Bushfire weather. http://www.bom.gov.au/weather-services/fireweather-centre/bushfire-weather/index.shtml. Accessed 21 Jan 2020.

Cal Fire. 2019. 2019 Incident Archive. https://www.fire.ca.gov/ incidents/2019. Accessed 21 Jan 2020.

Climate Action Tracker. 2019. Dec 2019 Update. https://climateac tiontracker.org/global/temperatures. Accessed 21 Jan 2020.

EASAC (European Academies' Science Advisory Council). 2018. Extreme weather events in Europe. Preparing for climate change adaptation: An update on EASAC's 2013 study. Leopoldina: EASAC.

Glasser, R. 2019. Special report: Preparing for the era of disasters. Barton: ASPI (Australian Strategic Policy Institute).

Global Panel. 2016. The cost of malnutrition. Why policy action is urgent. London: Global Panel on Agriculture and Food Systems for Nutrition.

Goodchild, M., N. Nargis, and E.T. d'Espaignet. 2018. Global economic cost of smoking-attributable diseases. BMJ Tobacco Control 27(1): 58-64.
Hansen, J., M. Sato, and R. Ruedy. 2012. Perception of climate change. PNAS 109(37): E2415-E2423.

Harvey, C. 2017. Here's what we know about wildfires and climate change. Scientific American. https://www.scientificamerican. com/article/heres-what-we-know-about-wildfires-and-climatechange. Accessed 21 Jan 2020.

Hunn, D., M. Dempsey, and M. Zaveri. 2018. Harvey's floods. Houston Chronicle. https://www.houstonchronicle.com/news/ article/In-Harvey-s-deluge-most-damaged-homes-were12794820.php. Accessed 21 Jan 2020.

IPCC (Intergovernmental Panel on Climate Change). 2018. Special report: Global warming of $1.5^{\circ} \mathrm{C}$. Geneva: IPCC.

Moody's. 2017. Climate change is forecast to heighten US exposure to economic loss placing short- and long-term credit pressure on US states and local governments. New York: Moody's.

NOAA (National Oceanic and Atmospheric Administration). 2019. What are El Niño and La Niña? https://oceanservice.noaa.gov/ facts/ninonina.html. Accessed 21 Jan 2020.

Rahmstorf, S. 2004. Stefan Rahmstorf (Contributor Bio's). http:// www.realclimate.org/?s=rahmstorf. Accessed 21 Jan 2020.

Schiermeier, Q. 2018. Droughts, heatwaves and floods: How to tell when climate change is to blame. Nature 560(7716): 20-22.

Schmidt, J. 2008. Deforestation costs to the world...Wow, big $\$ \$$. https://www.nrdc.org/experts/jake-schmidt/deforestation-costsworldwow-big. Accessed 21 Jan 2020.

Sharmila, S., and K.J.E. Walsh. 2018. Recent poleward shift of tropical cyclone formation linked to Hadley cell expansion. Nature Climate Change 8: 730-736.

Sneed, A. 2018. The next climate frontier: Predicting a complex domino effect. Scientific American. https://www.scientificamer ican.com/article/the-next-climate-frontier-predicting-a-complexdomino-effect. Accessed 21 Jan 2020.

SPC (Pacific Community), SPREP (Secretariat of the Pacific Regional Environment Programme), PIFS (Pacific Islands Forum Secretariat), UNDP (United Nations Development Programme), UNISDR (United Nations Office for Disaster Risk Reduction), and USP (University of the South Pacific). 2016. Framework for resilient development in the Pacific: An integrated approach to address climate change and disaster risk management (FRDP), 2017-2030. Suva: SPC Geoscience Division.

UNISDR (United Nations International Strategy for Disaster Reduction). 2015. Sendai framework for disaster risk reduction 20152030. Geneva: UNISDR.

UNISDR (United Nations International Strategy for Disaster Reduction). 2017. UNISDR annual report 2017. Geneva: UNISDR.

Wang, G., W. Cai, B. Gan, L. Wu, A. Santoso, X. Lin, Z. Chen, and M.J. McPhaden. 2017. Continued increase of extreme El Niño frequency long after $1.5^{\circ} \mathrm{C}$ warming stabilization. Nature Climate Change 7: 568-572.

Whiting, A. 2015. The economic impact of child abuse. https://www. weforum.org/agenda/2015/06/the-economic-impact-of-childabuse. Accessed 21 Jan 2020.

World Bank. 2016. Natural disasters force 26 million people into poverty and cost $\$ 520 \mathrm{bn}$ in losses every year, new World Bank analysis finds. Washington, DC: World Bank. https://www. worldbank.org/en/news/press-release/2016/11/14/natural-disas ters-force-26-million-people-into-poverty-and-cost-520bn-inlosses-every-year-new-world-bank-analysis-finds. Accessed 21 Jan 2020. 